\title{
Improvement of Phytase Activity by a New Saccharomyces cerevisiae Strain Using Statistical Optimization
}

\author{
Edi Franciele Ries and Gabriela Alves Macedo \\ Food Science Department, Faculty of Food Engineering, Campinas State University (UNICAMP), Monteiro Lobato Street 70, \\ 13083970 Campinas, SP, Brazil
}

Correspondence should be addressed to Gabriela Alves Macedo, gmacedo@fea.unicamp.br

Received 21 March 2011; Revised 18 June 2011; Accepted 21 June 2011

Academic Editor: Alane Beatriz Vermelho

Copyright ( 2011 E. F. Ries and G. Alves Macedo. This is an open access article distributed under the Creative Commons Attribution License, which permits unrestricted use, distribution, and reproduction in any medium, provided the original work is properly cited.

\begin{abstract}
Using statistical optimization, we enhanced the activity of phytase by a new Saccharomyces cerevisiae strain cultured in mineral medium. Concentrations of carbon source and inducer of phytase production were optimized using a $2^{2}$ full factorial CCD and response surface methodology (RSM). Urea was fixed as nitrogen source in culture medium $(0.15 \%$, w/v). The culture medium consisting of $2.5 \%$ sucrose and $0.5 \%$ sodium phytate optimally supported the maximum phytase activity. In addition, we found that culture of the yeast at $35^{\circ} \mathrm{C}$ with shaking at $150 \mathrm{rpm}$ supports maximum phytase production. The validity of this model was verified by culturing the organisms in flasks on a shaker. Using the optimized media and growth conditions, we obtained a 10-fold improvement in the production of phytase by $S$. cerevisiae.
\end{abstract}

\section{Introduction}

Phytate degradation is an important metabolic process in many biological systems. Although phytate is the major storage form of phosphorus found in cereals, grains, legumes, pollens, and seeds [1], it is not widely available to monogastric animals, such as swine and poultry. Consequently, inorganic phosphorus, a nonrenewable and expensive mineral, is added to the diets of pigs, fish, and poultry to meet their nutritional phosphorus requirements [2, 3]. However, any phosphorus unused by the animals' body is excreted, causing environmental problems in areas of intensive livestock production $[3,4]$. In addition, phytic acid acts as an antinutrient because it chelates nutritionally important metals, such as iron, zinc, magnesium, and calcium and binds proteins and lipids, thus diminishing the bioavailability of these important nutrients [5].

Phytase (myoinositol hexakisphosphate phosphohydrolase, EC 3.1.3.8) catalyzes the hydrolysis of phytate to myoinositol pentakisphosphate and orthophosphate. Improving the digestibility of proteins and increasing the availability of phosphorus and other minerals, which are usually chelated by phytic acid [6], diminishes the antinutritive properties of phytate, and prevents environmental pollution. Thus, the ideal enzyme for the catalysis of such processes should have high catalytic specificity, resistance to proteolysis [7], and stability at elevated temperatures and under acidic conditions [8].

The process of fermentation is significantly influenced by various physical and chemical factors. In addition, phytase production is affected by growth conditions, the strain and substrate used for culture, and the availability of nutrients [2]. Statistical plans are currently used to find ways to enhance phytase production at a reduced cost. The use of response surface methodology (RSM) in biotechnological processes has gained great importance in the optimization of enzyme production because it helps to determine the optimum parameters for enzyme activity [9-16].

Phytase is widely distributed in plants, animal tissues, and microorganisms. Phytases are produced by yeast either naturally [17-20] or by processes based on recombinant DNA technology using different yeast strains [21-26]. Saccharomyces cerevisiae possesses several properties that make it useful for use in biotechnological applications, such as its resistance to high sugar and alcohol concentrations [27] and a high growth rate at increasing temperatures [28]. Phytases 
have been studied in different yeast strains, such as baker's yeast [29], and an extracellular acid phytase from S. cerevisiae was recently purified and characterized [30]. Additionally, a phytase-producing yeast strain, identified as S. cerevisiae strain zi (EU188613), was isolated from soil samples from Sao Paulo, Brazil [31]. This strain is potentially a new source of thermostable phytases of commercial interest, particularly because the screen for this yeast was performed using gradual temperature increases. In this study, our aim was to optimize the medium composition and culture conditions to maximize the production of phytase by $S$. cerevisiae strain zi (EU188613) using statistical designs.

\section{Material and Methods}

2.1. Yeast and Preinoculum Preparation. The yeast strain was isolated from a sample of soil, identified as S. cerevisiae strain zi (EU188613) by molecular taxonomy [31] and deposited in the CBMAI (Coleção Brasileira de Microrganismos de Ambiente e Indústria) collection. The yeast cultures were maintained in assay vials containing yeast malt agar (YMA) and stored at $4^{\circ} \mathrm{C}$ until they were used for preparation of the preinoculum, which was done by suspending the spores in $2.5 \mathrm{~mL}$ of sterile water. The cell suspension was used to inoculate the culture medium.

2.2. Phytase Assay. Phytase production was measured using a colorimetric method by following the release of inorganic phosphate from phytic acid. Free inorganic phosphate was assayed in the culture supernatant based on the concentration of phosphate released after hydrolysis of sodium phytate by phytase [32]. For this purpose, $150 \mu \mathrm{L}$ of enzyme solution were mixed with $600 \mu \mathrm{L}$ of $0.1 \mathrm{M}$ Tris- $\mathrm{HCl}(\mathrm{pH} 7.0)$ supplemented with $2 \mathrm{mM}$ sodium phytate and $2 \mathrm{mM}$ of $\mathrm{CaCl}_{2}$, and incubated at $37^{\circ} \mathrm{C}$ for $30 \mathrm{~min}$. The reaction was then stopped by addition of $750 \mu \mathrm{L}$ of $5 \%$ trichloroacetic acid, after which $1.5 \mu \mathrm{L}$ of the color reagent were added to generate phosphomolybdate. The concentration of inorganic orthophosphate $(\mathrm{Pi})$ in this mixture was determined colorimetrically by measuring the absorbance of the solution at $700 \mathrm{~nm}$ using a Beckman Coulter DU640 Spectrophotometer (Fullerton, CA, USA). The color reagent was prepared fresh by mixing 4 volumes of $1.5 \%(\mathrm{w} / \mathrm{v})$ ammonium molybdate solution supplemented with $5.5 \%(\mathrm{v} / \mathrm{v})$ sulfuric acid and 1 volume of $2.7 \%(\mathrm{w} / \mathrm{v})$ ferrous sulfate solution. The results were compared to a standard curve prepared using $\mathrm{K}_{2} \mathrm{HPO}_{4}$ as a source of inorganic phosphate at concentrations ranging from 0.0448 to $2.8706 \mu \mathrm{M}$.

Phytase production was also assayed using the method proposed by Stockmann et al. [24] with adaptations for using a synthetic phosphatase substrate. This method is based on the hydrolysis of 4-nitrophenyl phosphate (4-NPP) to phosphate and p-nitrophenol. The substrate $(1000 \mu \mathrm{L}$ of $5 \mathrm{mM} 4$-NPP disodium salt hexahydrate) was added to a mixture of $500 \mu \mathrm{L}$ of $0.8 \mathrm{M}$ sodium acetate buffer ( $\mathrm{pH} 5.0$ ) and $500 \mu \mathrm{L}$ of enzyme solution. The mixture was incubated at $37^{\circ} \mathrm{C}$ for $10 \mathrm{~min}$, and the reaction was stopped by the addition of $2000 \mu \mathrm{L}$ of $0.1 \mathrm{~N} \mathrm{NaOH}$. The concentration of released p-nitrophenol was determined colorimetrically by measuring the absorbance of the mixture at $410 \mathrm{~nm}$ using a Beckman Coulter DU640 spectrophotometer (Fullerton, CA, USA). The results were compared to a standard curve prepared using p-nitrophenol at concentrations ranging from 0.0719 to $7.1891 \mu \mathrm{M}$.

One unit $(\mathrm{U})$ of phytase activity was defined as the concentration of inorganic phosphate, in $\mu \mathrm{mol}$, released per min per $\mathrm{mL}$ of enzyme preparation $(\mathrm{U} / \mathrm{mL})$ under defined reaction conditions.

2.3. Biomass Determination. To determine the dry weight of the yeast, the cell pellets were washed twice with distilled water and dried in preweighed tubes at $60^{\circ} \mathrm{C}$ to a constant weight.

2.4. Control Culture Medium and Conditions. Standard culture medium $(10 \mathrm{~g} / \mathrm{L}$ sucrose, $0.5 \mathrm{~g} / \mathrm{L}$ sodium phytate [purchased from Sigma-Aldrich, Steinheim, Germany], $3.0 \mathrm{~g} / \mathrm{L}$ $\left(\mathrm{NH}_{4}\right)_{2} \mathrm{SO}_{4}, 0.5 \mathrm{~g} / \mathrm{L} \quad \mathrm{MgSO}_{4} \cdot 7 \mathrm{H}_{2} \mathrm{O}, 0.5 \mathrm{~g} / \mathrm{L} \mathrm{KCl}, 0.001 \mathrm{~g} / \mathrm{L}$ $\mathrm{FeSO}_{4} \cdot 7 \mathrm{H}_{2} \mathrm{O}, 0.0075 \mathrm{~g} / \mathrm{L} \mathrm{MnSO}_{4} \cdot \mathrm{H}_{2} \mathrm{O}$ and $0.1 \mathrm{~g} / \mathrm{L} \mathrm{CaCl}_{2}$ ) was adjusted to a pH of 4.5 and autoclaved at $121^{\circ} \mathrm{C}$ and $1 \mathrm{~atm}$ for $15 \mathrm{~min}$. Fifteen milliliters of culture medium and $1 \mathrm{~mL}$ of yeast preinoculum were mixed in conical flasks of $50 \mathrm{~mL}$, which were incubated in a rotary shaker (TECNAL TE 421, Piracicaba, SP, BR) at $150 \mathrm{rpm}$ and $35^{\circ} \mathrm{C}$ for $120 \mathrm{~h}$. After allowing the yeast to grow, the flasks were centrifuged at $7100 \times \mathrm{g}$ and $10^{\circ} \mathrm{C}$ for $15 \mathrm{~min}$ in a Beckman Coulter Allegra X-22R centrifuge (Fullerton, CA, USA). The culture supernatant was then used directly for the phytase assay, and the pellet was used for biomass determinations after $12,24,36$, and $48 \mathrm{~h}$ for determination of the experimental fermentation time.

2.5. Optimization of the Medium Composition for the Production of Phytase Using RSM. The control culture medium was use and the carbon sources (sucrose) and the inducer of phytase production (sodium phytate) were further optimized in the synthetic medium by RSM and by using central composite design (CCD). One milliliter of yeast preinoculum was used in all the experiments. In this manner, we sought to determine the optimal concentrations of these compounds and to study their interactions. Urea was fixed as nitrogen source at concentration of $0.15 \%(\mathrm{w} / \mathrm{v})$. The concentrations of these two variables (sodium phytate concentration $(A)$ and sucrose concentration $(B)$ ) were optimized using the CCD plan and Statistica software (version 7.0). Each variable in the design was studied at five different levels (Table 1). A $2^{2}$ factorial design, with four axial points and three replicates at the center point and a total of 11 experiments were employed (Table 2). The average maximum phytase activity in S. cerevisiae cultured in sodium phytate substrate was measured after $36 \mathrm{~h}$ of fermentation. The behavior of the system can be explained by the following quadratic equation:

$$
Y=\beta_{0}+\beta_{1} A+\beta_{2} B+\beta_{11} A^{2}+\beta_{22} B^{2}+\beta_{12} A B,
$$

where $Y$ is the predicted response, $\beta_{0}$ is the intercept, $\beta_{1}$ and $\beta_{2}$ are linear coefficients, $\beta_{11}$ and $\beta_{22}$ are squared coefficients, 
TABLE 1: Concentration ranges of the medium components as analyzed by RSM.

\begin{tabular}{lccccccc}
\hline \multirow{2}{*}{ Factor } & \multirow{2}{*}{ Variables } & $\begin{array}{c}\text { Range } \\
\text { examined }\end{array}$ & \multicolumn{5}{c}{ Levels } \\
& & & $-\alpha$ & -1 & 0 & +1 & $+\alpha$ \\
\hline$A$ & $\begin{array}{c}\text { Sodium phytate } \\
(\% \mathrm{w} / \mathrm{v})\end{array}$ & $0.15-0.55$ & 0.15 & 0.2 & 0.35 & 0.5 & 0.55 \\
$B$ & Sucrose $(\% \mathrm{w} / \mathrm{v})$ & $0.5-2.5$ & 0.5 & 0.8 & 1.5 & 2.2 & 2.5 \\
\hline
\end{tabular}

TABLE 2: Experimental design and results for the optimization of the medium composition for phytase activity using RSM.

\begin{tabular}{lcccc}
\hline $\begin{array}{l}\text { Run } \\
\mathrm{n}^{\circ}\end{array}$ & $\begin{array}{c}\text { Sodium } \\
\text { phytate }(\% \mathrm{w} / \mathrm{v})\end{array}$ & $\begin{array}{c}\text { Sucrose } \\
(\% \mathrm{w} / \mathrm{v})\end{array}$ & $\begin{array}{c}\text { Phytase activity in } \\
\text { sodium phytate } \\
\text { medium }(\mathrm{U} / \mathrm{mL}) \\
\text { Experimental }\end{array}$ \\
\hline 1 & -1 & -1 & 0.35 & 0.34 \\
2 & +1 & -1 & 0.36 & 0.35 \\
3 & -1 & +1 & 0.35 & 0.34 \\
4 & +1 & +1 & 0.51 & 0.50 \\
5 & -1.41 & 0 & 0.29 & 0.29 \\
6 & +1.41 & 0 & 0.40 & 0.41 \\
7 & 0 & -1.41 & 0.34 & 0.35 \\
8 & 0 & +1.41 & 0.45 & 0.46 \\
9 & 0 & 0 & 0.43 & 0.43 \\
10 & 0 & 0 & 0.43 & 0.43 \\
11 & 0 & 0 & 0.43 & 0.43 \\
\hline
\end{tabular}

TABLE 3: Analysis of variance and regression analysis for the optimization of the medium composition for phytase activity by $S$. cerevisiae in sodium phytate substrate.

\begin{tabular}{lcccc}
\hline $\begin{array}{l}\text { Source of } \\
\text { variation }\end{array}$ & $\begin{array}{c}\text { Sum of } \\
\text { squares }\end{array}$ & $\begin{array}{c}\text { Degrees of } \\
\text { freedom }\end{array}$ & $\begin{array}{c}\text { Mean } \\
\text { square }\end{array}$ & $F$ value \\
\hline Regression & 0.037781 & 4 & 0.009445 & 24.22 \\
Residual & 0.002339 & 6 & 0.00039 & \\
Lack of fit & 0.002338 & 4 & 0.000585 & \\
Pure error & 0.000001 & 2 & & \\
Total & 0.04012 & 10 & & \\
\hline
\end{tabular}

Coefficient of determination $\left(R^{2}\right)=0.9417 ; F_{4 ; 6 ; 0.05}=4.53$.

$\beta_{12}$ is the interaction coefficient, and $A, B, A^{2}, B^{2}$ and $A B$ are the levels of the independent variables. The corresponding ANOVA values are shown in Table 3.

2.6. Optimization of the Fermentation Conditions for the Production of Phytase. The production of phytase in optimized medium was studied under different culture conditions. One milliliter of yeast preinoculum was used in all the experiments. To determine the optimum temperature $(A)$ and agitation $(B)$ for the production of phytase and to study their interactions, RSM using CCD was applied. The two independent variables $(A$ and $B)$ were studied at five different levels $(-\alpha,-1,0,+1,+\alpha$; Table 4$)$, and a total of 11 experiments were performed (Table 5 ). The average maximum phytase
TABLE 4: Temperature and agitation ranges as analyzed by RSM.

\begin{tabular}{|c|c|c|c|c|c|c|c|}
\hline \multirow[t]{2}{*}{ Factor } & \multirow[t]{2}{*}{ Variables } & \multirow{2}{*}{$\begin{array}{c}\text { Range } \\
\text { examined }\end{array}$} & \multicolumn{5}{|c|}{ Levels } \\
\hline & & & $-\alpha$ & -1 & 0 & +1 & $+\alpha$ \\
\hline$A$ & Temperature $\left({ }^{\circ} \mathrm{C}\right)$ & $25-45$ & 25 & 28 & 35 & 42 & 45 \\
\hline$B$ & Agitation (rpm) & $70-230$ & 70 & 93 & 150 & 207 & 230 \\
\hline
\end{tabular}

TABLE 5: Experimental design and results for the optimization of the fermentation conditions for phytase activity using RSM.

\begin{tabular}{lcccc}
\hline $\begin{array}{l}\text { Run } \\
\mathrm{n}^{\circ}\end{array}$ & $\begin{array}{c}\text { Temperature } \\
\left({ }^{\circ} \mathrm{C}\right)\end{array}$ & $\begin{array}{c}\text { Agitation } \\
(\mathrm{rpm})\end{array}$ & $\begin{array}{c}\text { Phytase activity in } \\
\text { sodium phytate }(\mathrm{U} / \mathrm{mL}) \\
\text { Experimental }\end{array}$ & Predicted \\
\hline 1 & -1 & -1 & 0.53 & 0.49 \\
2 & +1 & -1 & 0.45 & 0.46 \\
3 & -1 & +1 & 0.40 & 0.41 \\
4 & +1 & +1 & 0.37 & 0.43 \\
5 & -1.41 & 0 & 0.29 & 0.32 \\
6 & +1.41 & 0 & 0.36 & 0.31 \\
7 & 0 & -1.41 & 0.59 & 0.61 \\
8 & 0 & +1.41 & 0.58 & 0.54 \\
9 & 0 & 0 & 0.61 & 0.61 \\
10 & 0 & 0 & 0.62 & 0.61 \\
11 & 0 & 0 & 0.61 & 0.61 \\
\hline
\end{tabular}

activity in S. cerevisiae cultured in sodium phytate substrate was measured after $36 \mathrm{~h}$ of fermentation. The behavior of the system can be explained by the following quadratic equation:

$$
Y=\beta_{0}+\beta_{1} A+\beta_{2} B+\beta_{11} A^{2}+\beta_{22} B^{2}+\beta_{12} A B
$$

where $Y$ is the predicted response, $\beta_{0}$ is the intercept, $\beta_{1}$ and $\beta_{2}$ are linear coefficients, $\beta_{11}$ and $\beta_{22}$ are squared coefficients, $\beta_{12}$ is the interaction coefficient, and $A, B, A^{2}, B^{2}$ and $A B$ are the levels of the independent variables.

2.7. Statistical Analysis. The analyses were performed in triplicate, and the results are presented as the mean \pm standard deviation. The Tukey test was used to determine significant differences between the mean values for the different components. $P$ values of $\leq 0.05$ were considered statistically significant.

\section{Results and Discussion}

Prior to optimization, the experimental fermentation time was defined as $36 \mathrm{~h}$. The experiments were carried out at the center point at $12,24,36$, and $48 \mathrm{~h}$. The results indicated that yeast biomass increases with increased fermentation time. However, the activity of phytase when the yeast was cultured in both substrates increased only up to $36 \mathrm{~h}$ $(0.55 \pm 0.01 \mathrm{U} / \mathrm{mL}$ and $0.051 \pm 0.004$ in sodium phytate and 4 -NPP substrates, respectively) and decreased significantly after $48 \mathrm{~h}$. 
3.1. Optimization of the Medium Components for the Production of Phytase. Different concentrations of urea were analyzed $(0 ; 0.15$ and $0.30 \% \mathrm{w} / \mathrm{v})$ to determine the best concentration that promotes the production of phytase. Higher concentrations of urea result in decreased phytase activity when $S$. cerevisiae is cultured in sodium phytate substrate. At a concentration of $0.15 \%$ urea, the activity of phytase was $0.41 \mathrm{U} / \mathrm{mL}$, while at $0.30 \%$ urea we observed an activity of $0.33 \mathrm{U} / \mathrm{mL}$. Urea is the preferred nitrogen sources for the production of phytase by Aspergillus ficuum [5] and Pichia anomala [13].

The concentrations of sucrose and sodium phytate were further optimized by RSM using CCD, and the data were analyzed using the analysis of variance (ANOVA). Table 1 shows the ranges of the selected variables analyzed for their effects on the production of phytase, and the predicted and observed responses are shown in Table 2. The effects of these variables on the activity of phytase in S. cerevisiae cultured in sodium phytate substrate can be predicted by the model:

$$
Y=0.4333+0.0406 A+0.0387 B-0.0393 A^{2}+0.0355 A B,
$$

where $Y$ is the activity $(\mathrm{U} / \mathrm{mL})$ of phytase in sodium phytate, $A$ is the concentration of sodium phytate, and $B$ is the concentration of sucrose. The corresponding ANOVA values are shown in Table 3. The coefficient of determination $\left(R^{2}\right)$ was 0.9417 , which accounts for the $94.17 \%$ variability of the model. The $R^{2}$-value should be between 0 and 1 , and a value $\geq 0.75$ indicates aptness of the model [13]. The ANOVA shows a high performance of the $F$-value for the regression analysis (the calculated values are approximately 5-fold higher than those listed), which indicates that the terms of the model are significant. For the analysis of the activity of phytase in response to sodium phytate, the quadratic parameter for the sucrose concentration was not statistically significant $(P \leq 0.05)$ and was added to the lack of fit.

The three-dimensional plot (Figure 1) shows the optimal concentrations and interactions of the sodium phytate and sucrose variables for the production of phytase. At high concentrations of sodium phytate and sucrose $(0.55 \%$ and $2.5 \% \mathrm{w} / \mathrm{v}$, respectively), we observed an increase in the production of phytase. The maximum predicted activity for phytase was $0.50 \mathrm{U} / \mathrm{mL}$, while the experimental activity was $0.51 \mathrm{U} / \mathrm{mL}$, indicating that the predicted and experimental values were in agreement.

The statistical model for phytase activity in response to sodium phytate was validated by ANOVA and by repeating the experiments using the optimized conditions. Experimentally, we found the activity of phytase to be $0.49 \pm 0.01 \mathrm{U} / \mathrm{mL}$, while the predicted activity was $0.50 \mathrm{U} / \mathrm{mL}$. Based on these results, sucrose at a concentration of $2.5 \%$ was used to further optimize the fermentation conditions, and due to its high cost, we used sodium phytate at a concentration of $0.5 \%$.

3.2. Optimization of the Fermentation Conditions for the Production of Phytase. The temperature and agitation conditions were also optimized by RSM using CCD. Table 4 shows

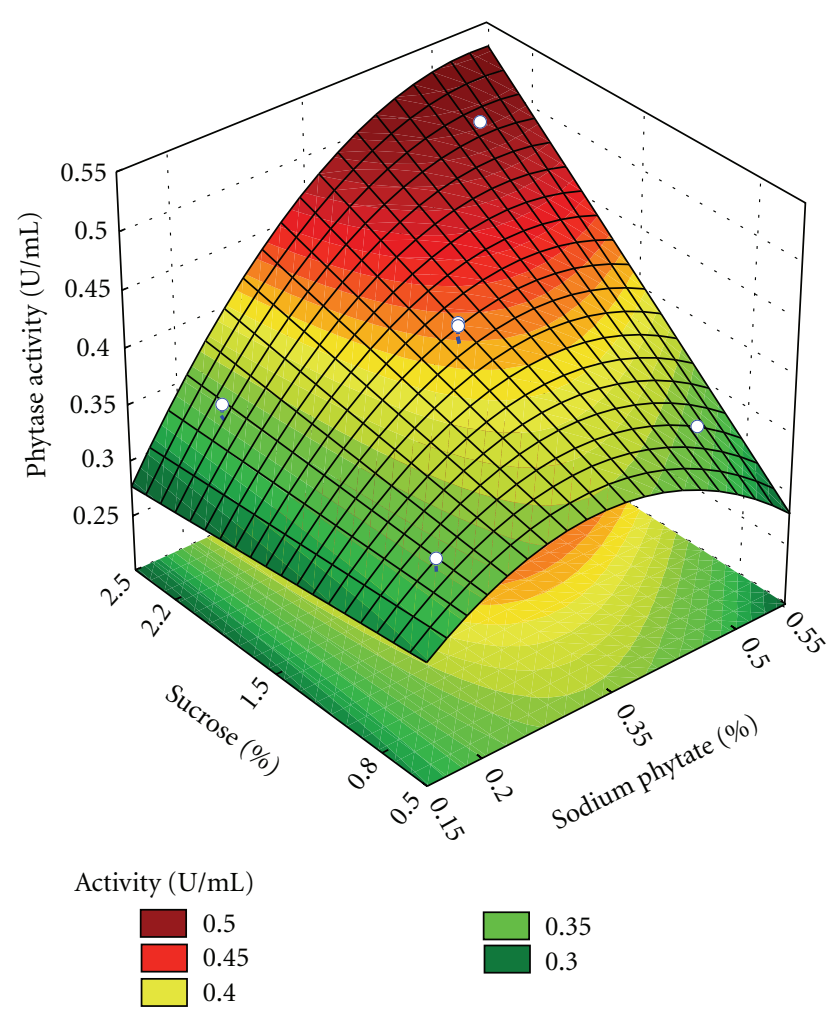

FIGURE 1: Response surface graph showing the effect of the interaction between sodium phytate and sucrose on the activity of phytase.

TABle 6: Analysis of variance and regression analysis for the optimization of the fermentation conditions for phytase activity by $S$. cerevisiae in sodium phytate substrate.

\begin{tabular}{lcccc}
\hline $\begin{array}{l}\text { Source of } \\
\text { variation }\end{array}$ & $\begin{array}{c}\text { Sum of } \\
\text { squares }\end{array}$ & $\begin{array}{c}\text { Degrees of } \\
\text { freedom }\end{array}$ & $\begin{array}{c}\text { Mean } \\
\text { square }\end{array}$ & $F$ value \\
\hline Regression & 0.12658 & 1 & 0.13162 & 57.59 \\
Residual & 0.01978 & 9 & 0.001643 & \\
Lack of fit & 0.01972 & 7 & 0.002818 & \\
Pure error & 0.00006 & 2 & 0.00003 & \\
Total & 0.14636 & 10 & & \\
\hline
\end{tabular}

Coefficient of determination $\left(R^{2}\right)=0.8648 ; F_{1 ; 9 ; 0.05}=5.12$.

the different temperature and agitation ranges analyzed for their effects on phytase production, and Table 5 shows the experimental and predicted phytase activity values obtained. The effects of these variables on the activity of phytase in $S$. cerevisiae cultured in sodium phytate substrate can be predicted by the model:

$$
Y=0.6133-0.1485 A^{2}
$$

where $Y$ is the activity of phytase $(\mathrm{U} / \mathrm{mL})$ in sodium phytate and $A$ is the temperature. This optimized model for the activity of phytase in response to sodium phytate was validated by ANOVA, and the results are shown in Table 6.

The quadratic parameter for the temperature was a significant term in the model for phytase production $(P \leq$ $0.05)$. The $R^{2}$ was calculated to be 0.8648 , which accounts for 


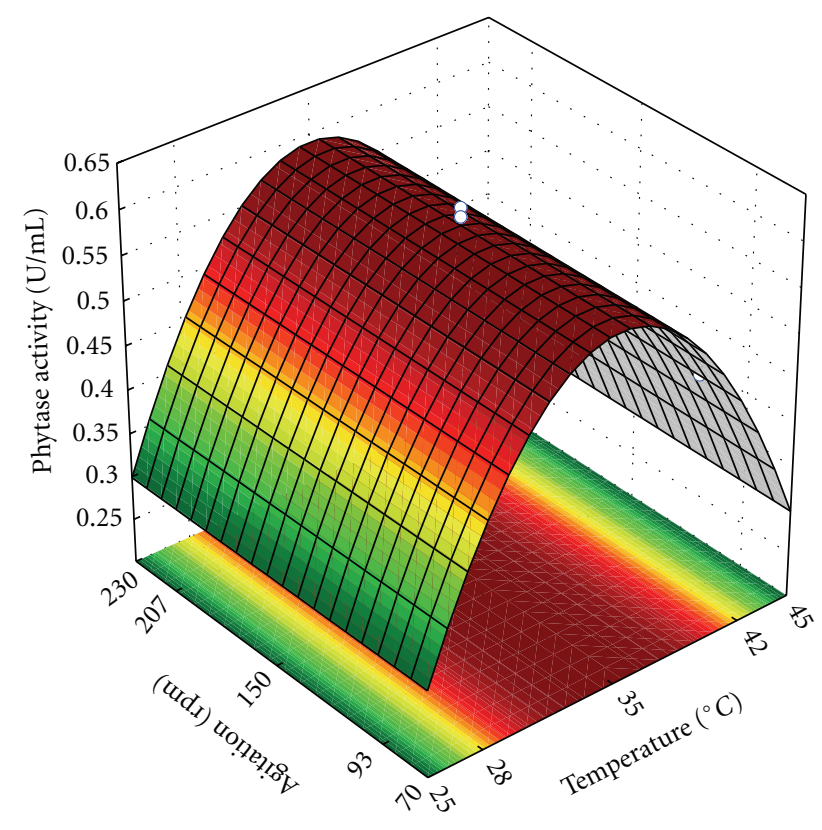

Activity $(\mathrm{U} / \mathrm{mL})$

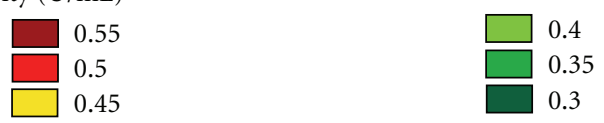

FIGURE 2: Response surface graph showing the effect of the interaction between temperature and agitation on the activity of phytase.

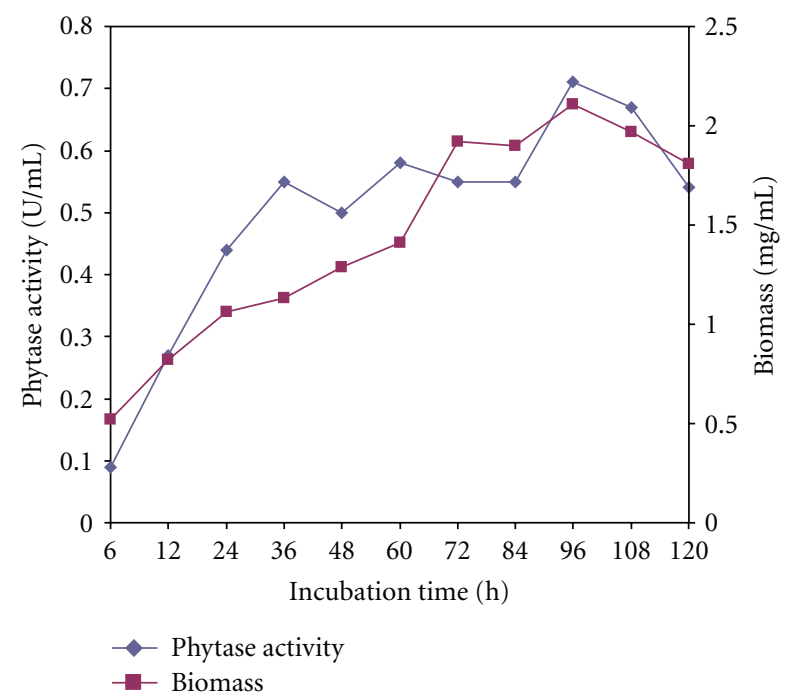

Figure 3: Phytase activity and yeast biomass at different time points.

the $86.48 \%$ variability of the model. The high $F$-value for the regression analysis (the calculated values are approximately 11-fold higher than those listed) indicates that the terms of the model are significant.

The three-dimensional plot shows the interaction between temperature and agitation for the production of phytase (Figure 2). The results show that the highest phytase activity $(0.62 \mathrm{U} / \mathrm{mL})$ in response to sodium phytate was obtained at central point conditions $\left(35^{\circ} \mathrm{C}\right.$ and $\left.150 \mathrm{rpm}\right)$, which were previously used. The maximum experimental phytase activity obtained was $0.62 \mathrm{U} / \mathrm{mL}$, whereas the predicted value was $0.61 \mathrm{U} / \mathrm{mL}$.

The model was also validated by repeating the experiments using the optimized conditions. The predicted activity of phytase was $0.61 \mathrm{U} / \mathrm{mL}$, while the experimental activity was $0.58 \pm 0.02 \mathrm{U} / \mathrm{mL}$.

The phytase activity obtained in unoptimized medium was $0.06 \mathrm{U} / \mathrm{mL}$ after $24 \mathrm{~h}$ of fermentation by $S$. cerevisiae. After optimization of the medium composition and the fermentation conditions, the activity of phytase in response to sodium phytate was approximately 10 -fold higher $(0.62 \mathrm{U} /$ $\mathrm{mL}$ ). After statistical optimization, the activity of phytase increased 1.75-fold in P. anomala cultured in synthetic medium [10], 1.7-fold in Aspergillus ficuum [11], 1.3-fold in Rhizomucor pusillus [12], 3.73-fold in Sporotrichum thermophile [15], and 1.8-fold in M. racemosus [33].

The activity of phytase in response to sodium phytate after $120 \mathrm{~h}$ of fermentation by S. cerevisiae was analyzed using the following optimized conditions: $0.5 \%$ sodium phytate, $2.5 \%$ sucrose, $35^{\circ} \mathrm{C}$ and $150 \mathrm{rpm}$. The activity of phytase in response to sodium phytate and the biomass of $S$. cerevisiae at different time points are shown in Figure 3. The activity of phytase and the biomass of the yeast increased progressively over time, and the maximum phytase activity (0.710 \pm $0.002 \mathrm{U} / \mathrm{mL})$ and biomass $(2.11 \pm 0.03 \mathrm{mg} / \mathrm{mL})$ were obtained after $96 \mathrm{~h}$ of fermentation. However, the enzyme yield significantly declined after further incubation times $(P \leq 0.05)$, which is possibly due to the reduced levels of nutrients available in the medium, as reported by Roospesh et al. [34]. In agreement with this result, the maximum phytase activity and biomass for $M$. racemosus was reported to be obtained after $96 \mathrm{~h}$ of fermentation, suggesting a relationship between enzyme production and maximum growth [34].

S. cerevisiae produces extracellular phytase in simple mineral medium, and RSM has proved to be effective for optimizing the activity of phytase. Few studies have reported the use of RSM to improve the production of phytase by yeast, and this is the first study that was carried out to enhance the production of phytase by $S$. cerevisiae. Thus, this yeast strain has potential applications for the reduction of phytate in animal feed.

\section{Acknowledgment}

The authors wish to thank the Fundação de Amparo à Pesquisa do Estado de São Paulo (FAPESP) for financial support.

\section{References}

[1] A. Pandey, G. Szakacs, C. R. Soccol, J. A. Rodriguez-Leon, and V. T. Soccol, "Production, purification and properties of microbial phytases," Bioresource Technology, vol. 77, no. 3, pp. 203-214, 2001. 
[2] P. Vats and U. C. Banerjee, "Production studies and catalytic properties of phytases (myo-inositolhexakisphosphate phosphohydrolases): an overview," Enzyme and Microbial Technology, vol. 35, no. 1, pp. 3-14, 2004.

[3] A. Casey and G. Walsh, "Identification and characterization of a phytase of potential commercial interest," Journal of Biotechnology, vol. 110, no. 3, pp. 313-322, 2004.

[4] G. A. Walsh, R. F. Power, and D. R. Headon, "Enzymes in the animal-feed industry," Trends in Food Science and Technology, vol. 5, no. 3, pp. 81-87, 1994.

[5] S. J. Howson and R. P. Davis, "Production of phytate-hydrolysing enzyme by some fungi," Enzyme and Microbial Technology, vol. 5, no. 5, pp. 377-382, 1983.

[6] U. Konietzny and R. Greiner, "Molecular and catalytic properties of phytate-degrading enzymes (phytases)," International Journal of Food Science and Technology, vol. 37, no. 7, pp. 791812, 2002.

[7] P. H. Selle and V. Ravindran, "Microbial phytase in poultry nutrition," Animal Feed Science and Technology, vol. 135, no. 1-2, pp. 1-41, 2007.

[8] A. Casey and G. Walsh, "Purification and characterization of extracellular phytase from Aspergillus niger ATCC 9142," Bioresource Technology, vol. 86, no. 2, pp. 183-188, 2003.

[9] K. Sunitha, J. K. Lee, and T. K. Oh, "Optimization of medium components for phytase production by Escherichia coli using response surface methodology," Bioprocess Engineering, vol. 21, no. 6, pp. 477-481, 1999.

[10] A. Vohra and T. Satyanarayana, "Statistical optimization of the medium components by response surface methodology to enhance phytase production by Pichia anomala," Process Biochemistry, vol. 37, no. 9, pp. 999-1004, 2002.

[11] B. Bogar, G. Szakacs, J. C. Linden, A. Pandey, and R. P. Tengerdy, "Optimization of phytase production by solid substrate fermentation," Journal of Industrial Microbiology and Biotechnology, vol. 30, no. 3, pp. 183-189, 2003.

[12] B. S. Chadha, G. Harmeet, M. Mandeep, H. S. Saini, and N. Singh, "Phytase production by the thermophilic fungus Rhizomucor pusillus," World Journal of Microbiology \& Biotechnology, vol. 20, no. 1, pp. 105-109, 2004.

[13] P. Kaur and T. Satyanarayana, "Production of cell-bound phytase by Pichia anomala in an economical cane molasses medium: optimization using statistical tools," Process Biochemistry, vol. 40, no. 9, pp. 3095-3102, 2005.

[14] B. Singh and T. Satyanarayana, "A marked enhancement in phytase production by a thermophilic mould Sporotrichum thermophile using statistical designs in a cost-effective cane molasses medium," Journal of Applied Microbiology, vol. 101, no. 2, pp. 344-352, 2006.

[15] B. Singh and T. Satyanarayana, "Improved phytase production by a thermophilic mould Sporotrichum thermophile in submerged fermentation due to statistical optimization," Bioresource Technology, vol. 99, no. 4, pp. 824-830, 2008.

[16] X. Y. Li, Z. Q. Liu, and Z. M. Chi, "Production of phytase by a marine yeast Kodamaea ohmeri BG3 in an oats medium: optimization by response surface methodology," Bioresource Technology, vol. 99, no. 14, pp. 6386-6390, 2008.

[17] L. Segueilha, C. Lambrechts, H. Boze, G. Moulin, and P. Galzy, "Purification and properties of the phytase from Schwanniomyces castellii," Journal of Fermentation and Bioengineering, vol. 74, no. 1, pp. 7-11, 1992.

[18] C. Lambrechts, H. Boze, L. Segueilha, G. Moulin, and P. Galzy, "Influence of culture conditions on the biosynthesis of
Schwanniomyces castelli phytase," Biotechnology Letters, vol. 15, no. 4, pp. 399-404, 1993.

[19] K. Sano, H. Fukuhara, and Y. Nakamura, "Phytase of the yeast Arxula adeninivorans," Biotechnology Letters, vol. 21, no. 1, pp. 33-38, 1999.

[20] A. Vohra and T. Satyanarayana, "Phytase production by the yeast, Pichia anomala," Biotechnology Letters, vol. 23, no. 7, pp. 551-554, 2001.

[21] A. F. Mayer, K. Hellmuth, H. Schlieker et al., "An expression system matures: a highly efficient and cost-effective process for phytase production by recombinant strains of Hansenula polymorpha," Biotechnology and Bioengineering, vol. 63, no. 3, pp. 373-381, 1999.

[22] Y. Han, D. B. Wilson, and X. G. Lei, "Expression of an Aspergillus niger phytase gene (phyA) in Saccharomyces cerevisiae," Applied and Environmental Microbiology, vol. 65, no. 5, pp. 1915-1918, 1999.

[23] Y. Han and X. G. Lei, "Role of glycosylation in the functional expression of an Aspergillus niger phytase (phyA) in Pichia pastoris," Archives of Biochemistry and Biophysics, vol. 364, no. 1, pp. 83-90, 1999.

[24] C. Stockmann, M. Losen, U. Dahlems, C. Knocke, G. Gellisse, and J. Buchs, "Effect of oxygen supply on passaging, stabilizing and srening of recombinant Hansenula polymorpha production strains in test tube cultures," FEMS Yeast Research, vol. 4, pp. 195-205, 2003.

[25] H. Huang, L. Huiying, P. Yang et al., "A novel phytase with preferable characteristics from Yersinia intermedia," Biochemical and Biophysical Research Communications, vol. 350, no. 4, pp. 884-889, 2006.

[26] M. J. Guo, Y. P. Zhuang, J. Chu et al., "Production and purification of a novel thermostable phytase by Pichia pastoris FPHY34," Process Biochemistry, vol. 42, no. 12, pp. 1660-1665, 2007.

[27] H. K. Jung, C. D. Park, D. H. Bae, and J. H. Hong, "Isolation of alcohol-tolerant amylolytic Saccharomyces cerevisiae and its application to alcohol fermentation," Food Science and Biotechnology, vol. 17, no. 6, pp. 1160-1164, 2008.

[28] S. D. Kim, M. K. Kim, C. J. Woo, C. H. Rhee, and S. H. Lee, "Characterization of psychrophilic yeast in Kimchi," Food Science and Biotechnology, vol. 9, pp. 277-279, 2000.

[29] N. R. Nayini and P. Markakis, "The phytase of yeast," Lebensmittel Wissenschaft \& Technologie, vol. 17, no. 1, pp. 24-26, 1984.

[30] M. Jin-In, S. Won-Seo, D. C. Kim, and N. Soon-Oh, "Purification and biochemical properties of an extracellular acid phytase produced by the Saccharomyces cerevisiae CY strain," Process Biochemistry, vol. 44, no. 1, pp. 122-126, 2009.

[31] E. F. Ries and G. A. Macedo, "Progressive screening of thermostable yeasts for phytase production," Food Science and Biotechnology, vol. 18, pp. 655-660, 2009.

[32] M. Shimizu, "Purification and characterization of Phytase from Bacillus subtilis (natto) N-77," Bioscince Biotechnology and Biochemistry, vol. 56, pp. 1266-1269, 1992.

[33] B. Bogar, G. Szakacs, A. Pandey, S. Abdulhameed, J. C. Linden, and R. P. Tengerdy, "Production of phytase by Mucor racemosus in solid-state fermentation," Biotechnology Progress, vol. 19, no. 2, pp. 312-319, 2003.

[34] K. Roopesh, S. Ramachandran, K. M. Nampoothiri, G. Szakacs, and A. Pandey, "Comparison of phytase production on wheat bran and oilcakes in solid-state fermentation by Mucor racemosus," Bioresource Technology, vol. 97, no. 3, pp. 506-511, 2006. 

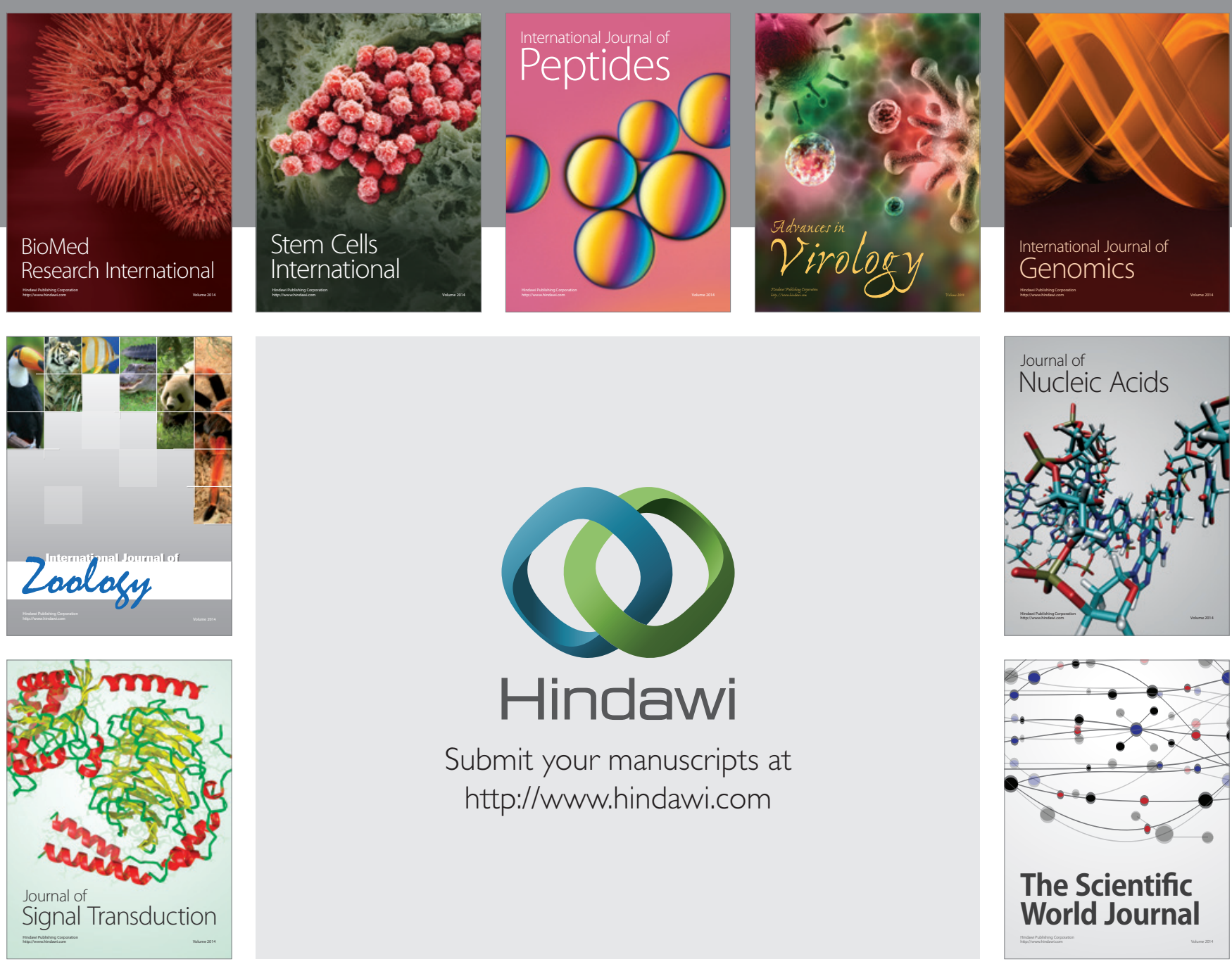

Submit your manuscripts at

http://www.hindawi.com
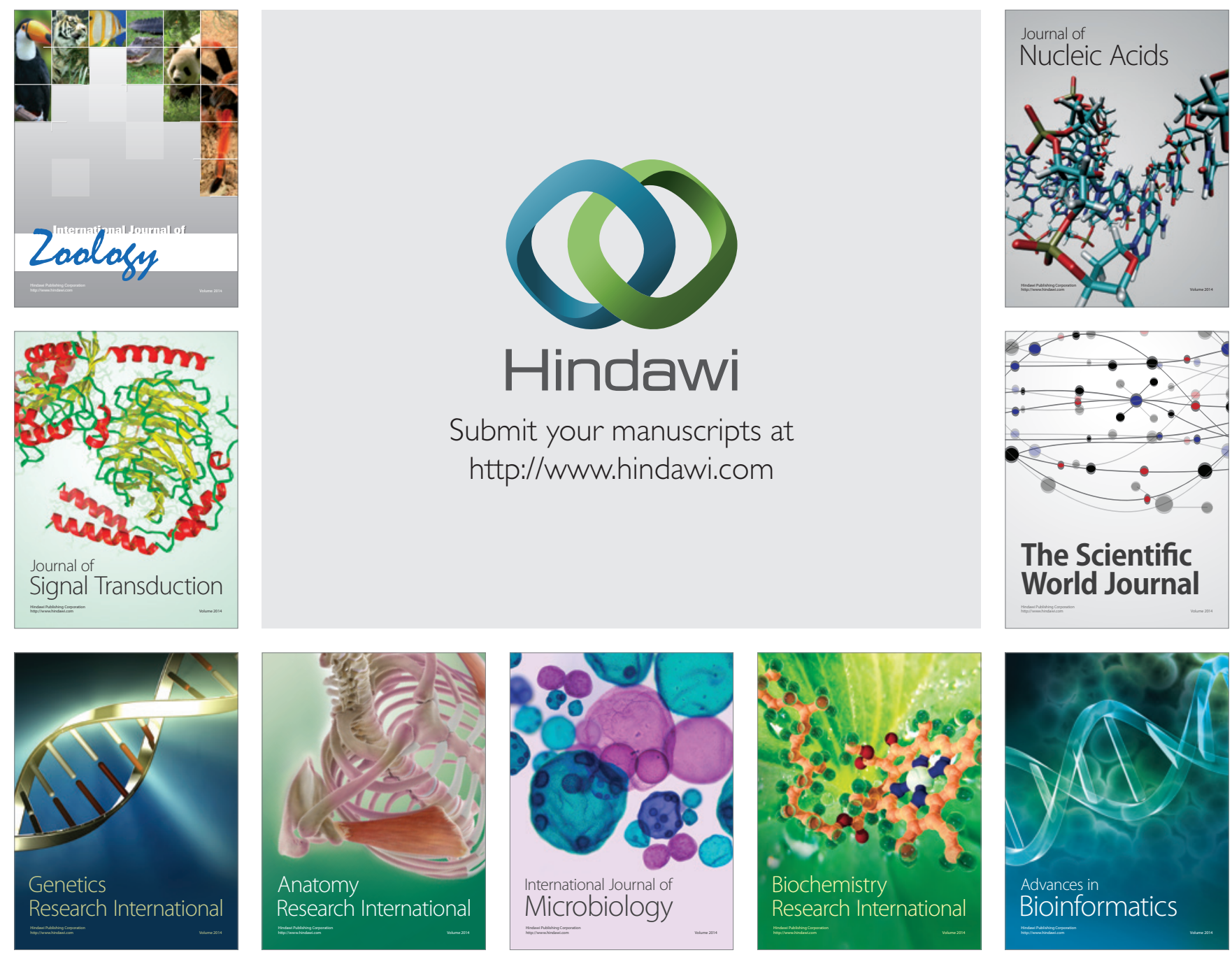

The Scientific World Journal
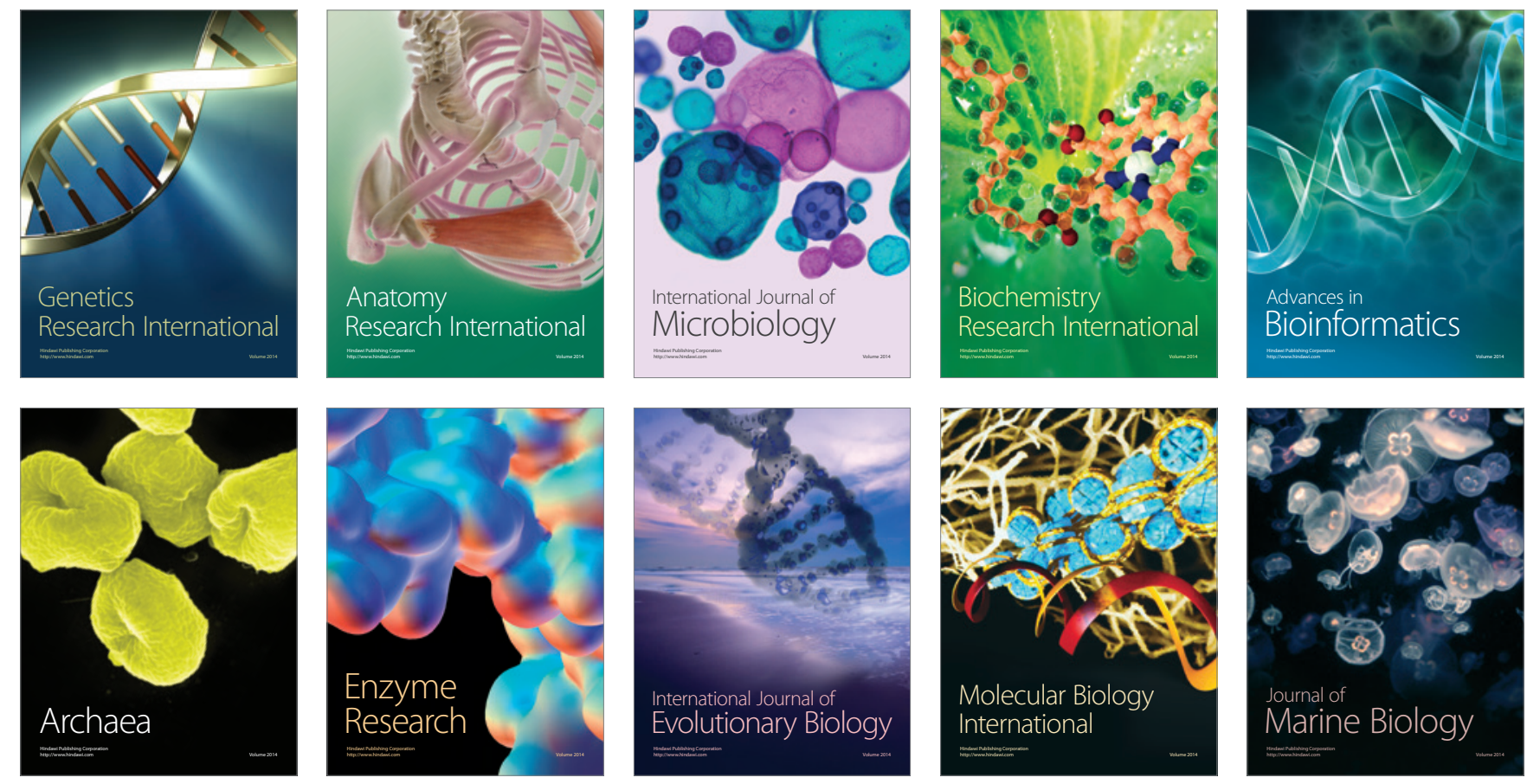